\title{
The Effect of Employee Satisfaction on Service Quality Through Delivery and Professionalism in Labor and Industrial Agency of Padang City
}

\author{
$1^{\text {st }}$ Wenny Astuti \\ Student at Master \\ Program in Public Administration, \\ Universitas Negeri Padang, \\ Padang, Indonesia \\ wennyastuty93@gmail.com
}

\author{
$2^{\text {nd }}$ Dasman Lanin* \\ Professor Public Administration, \\ Universitas Negeri Padang, \\ Padang, Indonesia \\ dasmanlanin@gmail.com \\ $3^{\text {rd }}$ Syamsir \\ Senior Lecturer Public Administration, \\ Universitas Negeri Padang, \\ Padang, Indonesia \\ syamsirsaili@yahoo.com
}

\begin{abstract}
This study aimed to explain the effect of employee satisfaction on service quality through delivery and profession nalism both directly and indirectly in the office of Labor and Industrial Agency of Padang City. Employee satisfaction in this study was divided into three dimensions of satisfaction, namely job satisfaction, equity satisfaction and disconfirmation satisfaction. This study tried to prove the influence of the exogenous variables on the endogenous variable. The method used in this study was quantitative associative with the subject of employees in the Labor and Industrial Agency of Padang City. Sample was determined through proportionate stratified random sampling. By using the Slovin formula, sample of 47 respondents was obtained. In this study the data were collected using a Likert scale questionnaire which has been tested for its validity and
\end{abstract}

\section{INTRODUCTION}

In every aspect of life, human beings cannot be separated from the name of needs. Fulfillment of human needs is one of them relates to the desire to obtain service.In the era of globalization at this time, which is an indicator of the success of a good service is satisfaction. Satisfaction is defined by the reliability. Before analyzing with path analysis model, the classical assumption and regression tests were first performed. Hypothesis test results prove the existence of a significant influence of each exogenous variable (job satisfaction, equity satisfaction and disconfirmation satisfaction) on endogenous variables (delivery, professio nalism and service quality) both simul taneously and partially. Each of these variables had a different influence on the quality of service in the Labor and Industrial Agency of Padang City. The implication of theoretical research was that the theory used in this study was still quite actual and relevant so that this study did not abort existing theories, but could strengthen the theory.

Keywords-Employee Satisfaction, Service Quality, Delivery and Professionalism

onset of feeling glad someone on the work of others, work, employer and workplace environment. Satisfaction would arise if the expectations and the reality of equal or exceed the desired expectations. Customer satisfaction is the benchmark for a quality service, so the success or failure of services related to customer satisfaction. Customers in 
fact not just limited to recipients of government services. Customers consist of two, internal and external customers. Satisfaction as a result of service will be directly proportional to the internal customer satisfaction is the government itself. The government here to act as service providers to the needs of the community.
In the initial survey conducted based on data obtained that can be identified that the staff at the Labor and Industrial Agency of Padang City yet have the motivation and high morale in achieving a quality service for customers. It is illustrated in the diagram employee attendance during January and February 2018 the following.

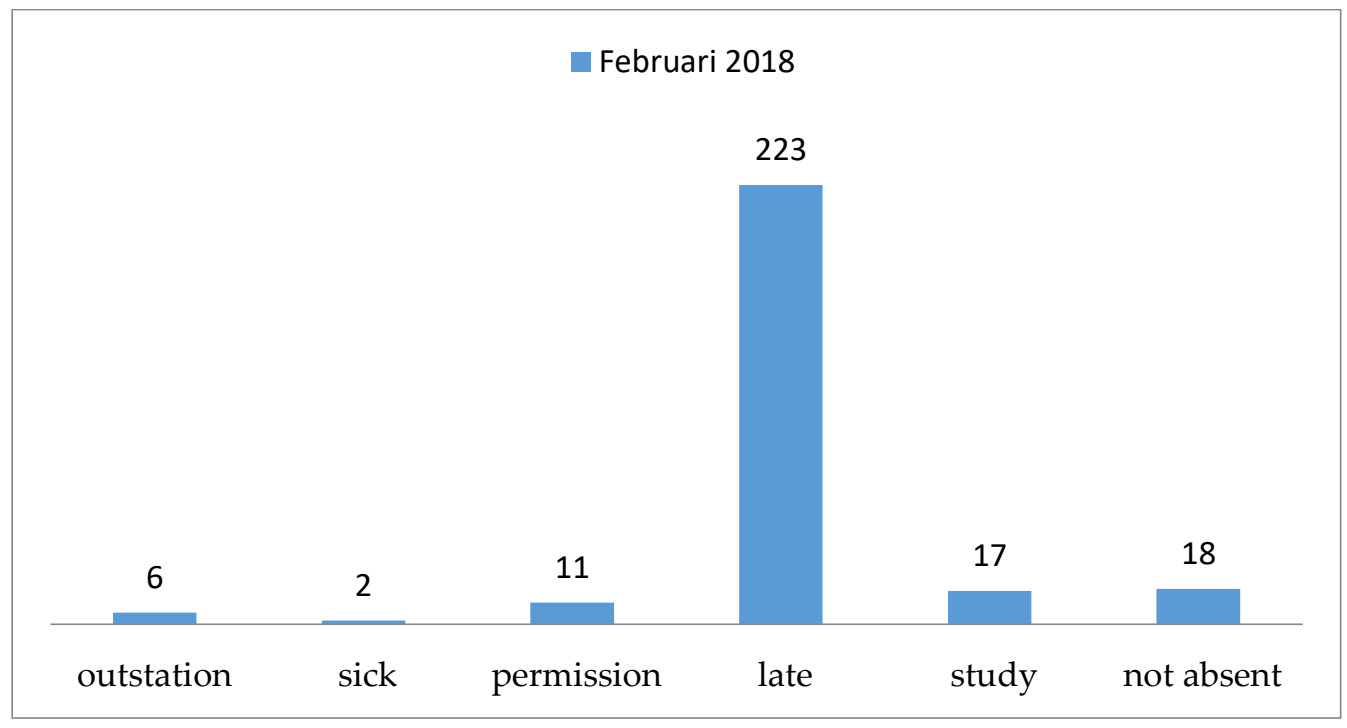

Figure 1.Presence of Staff Department of Labor and Industry

Source: Sub Division General Department of Labor and Industry Padang (2018)

From the data employee attendance table in January and February 2018, the researchers present a report based on six categories of information such as employee attendance foreign service, illness, late entry, study and not taking a hiatus. In the table 1 can be seen that the highest percentage of employees delay is a time delay 223 employees, it is becoming a major ratings factor in employee abstein in the Labor and Industrial Agency of Padang City. The second order, there are 18 times the employee does not take absent presence during the months of January, the permission for the education, licenses, Foreign Service and sickness. Lowest employee commitment and employee morale in realizing of course influenced by the low performance of employee satisfaction.

Labor and Industrial Agency of Padang City is a regional organization with the authority of the field of labor and industry. Professionalism is important to realize a good quality service for the customer. In an employee needed a reliable organization and work according to his ability. Professional or not an employee is determined by the satisfaction of employees towards their work and satisfaction with what they receive from the organization. When professional employees work would affect the delivery of services to customers who need the service. The purpose of the passage of employee satisfaction. If the employee satisfaction has been reached then it will also indirectly affect the quality of service provided to the customer/community. Based on the exposure of the background and the subject of her top so that the title and the purpose of this study was to analyze the influence of employee satisfaction on quality of service through service delivery and professionalism working at the labor and industrial agency of padang city.

\section{Employee Satisfaction}

Employees can be said to be satisfied from the work results. Satisfaction obtain employment is one of the important elements in the organization. Each individual employee 
has a different job satisfaction, despite being in the same type of work this case depends on the level of need and the systems that act on him. According to [1] provides a definition which states that job satisfaction is an emotional state that is happy or positive emotions are derived from the assessment of work or work experience person. In this research, employee satisfaction can be divided into three types, namely the satisfaction of both the employee satisfaction job satisfaction, equity satisfaction, disconfirmation satisfaction.

Equity satisfaction or equity theory assumes that customers will assess the ratio of the results (outcomes) that they earn and the input (input) they provide, compared to the results and other citizen input in a transaction service [2]. The main component of the theory of justice is input, results, justice and injustice. Employee input ratio will compare his results with the results of the other input ratio. Indicators used to assess the satisfaction of equity are: 1) the services provided; 2) compliance with expectations; and 3) justice. This satisfaction can be determined by looking at the model of disconfirmation, that is if reality/performance $(\mathrm{K})<$ Hope $(\mathrm{H})$, then apply negative disconfirmation or dissatisfaction, if $\mathrm{K}>\mathrm{H}$, then apply positive disconfirmation or satisfied and if $\mathrm{K}=\mathrm{H}$, then it neutral. The indicators used for the variable leads to more satisfaction disconfirmation satisfaction consisting of expectations and performance.

Service quality

Quality of service as a whole according to (2004) [3] is the expected level of excellence and control over the level of excellence to meet customer desires. Meanwhile, according [4] defines that quality of service is a measure of how good the level of services provided in accordance with customer expectations. Support the definition proposed by the [4] stated that the primary factor being the assessment of the quality of service is a service that is expected by the customer (expected service) and perception of the service (perceived service). Perceptions of Service, an assessment of the performance of the services customers acquired as a form of response to the services provided; Expectations/ Customer Expectations can be used as benchmarking customer expectations of quality and satisfaction. Customer expectations can be formed before and after the service received.

In principle, service quality is focused on activities and efforts to meet the needs and desires of customers as well as the accuracy of its services to balance customer expectations. In other words, there is a major factor affecting the quality of services, i.e. services that are expected and services are perceived. In a study conducted research and [5], that he had concluded there were at least five indicators of service quality (SERVQUAL); first, tangibles, physical evidence of the ability of a company to demonstrate its existence to external parties. Appearance and capabilities of the company's physical infrastructure and the state of the surrounding environment is tangible evidence of the services provided by the service provider.

Second, reliability; reliability of the ability of the organization to provide services as promised are accurate and reliable. Performance must be in accordance with customer expectations mean timeliness, the same service to all customers without error, sympathetic attitude, and with high accuracy. Third, responsiveness, responsiveness is an ability to assist and provide fast service (responsiveness) and the right to the customer with clear information. Forth, assurance; guarantees and assurances that knowledge, politeness, and the ability of an organization's employees to gain confidence of the customers to the company consists of several components; communications, credibility, safety (security), competent, and politeness (courtesy). Fifth, Empathy; which provides a genuine concern and a private individual or given to customers by striving to understand the desires of consumers.

\section{Service Delivery}

Delivery of services is the spearhead of service. In connection with the arrival of products service to the user, it will have an impact on people's satisfaction regarding the 
quality assessment of the approach to the service association. False of organization's internal capabilities with the ability to increase the level of customer satisfaction in providing services or the approach is to use the concept of service delivery. Delivery of services is the purpose of the service design process by analyzing the various alternatives that will be used to realize the arrival of service to customers. [6] explains that the design of the service delivery system includes aspects of facility location, facility layout, job design, customer engagement, gear selection, and management of service capacity.

According to [6] also describes the service delivery system is a "service delivery systems are a combination of people, technology and other internal and external elements that make up your organization's method of getting its product and service to customer "(the service delivery system is a combination of people, technology, internal and external elements that make the organization step in obtaining results and customer service)". The indicators used in the study: 1) the end result (after sales service); 2) adjustment to customer requirements (level of accuracy and comfort); 3) how to deal with problems (management of customer handling); 4) commitment to the customer (available). According to [7] that the operating system services are part of the total service system in which inputs will be processed and the elements of the product services have been created. Service delivery system is part of a total system of service, where final preparation of the elements of the case and the products are delivered to customers including the element of service operations.

\section{Professionalism}

In providing services and fulfill the rights of the community demanded a public servant is able to give his best. A professional employee who will give their best performance in accordance with the duties and functions. According [8] professionalism is the reliability and expertise in performing the tasks so done with high quality, timely manner, accurately, and with the procedure that is easily understood and followed by the customers. Furthermore [9] revealed that the professionalism is an attitude or state in performing work requires expertise through education and specific training and performed as a work that became a source of income.Professionalism of personnel in relation to public organizations by [10] is described as a form of the ability to recognize the needs of the community, to set the agenda, prioritize services, and develop service programs according to the needs and aspirations of the community or termed responsiveness.

[11] stated that the factor of professionalism should get more emphasis in order to achieve satisfaction for users of the service and it is rewarding to be able to provide a quality service to the public. The indicators used in the study: 1) competency/skills; 2) fairness (equity); 3) knowledge and ability (accountability); 4) proficiency (responsiveness).

\section{Conceptual Framework}

The conceptual framework is intended as a concept to explain how much influence and relationships between variables to be studied by the formulation of the problem. In this case, employee satisfaction, employee job satisfaction consist of satisfaction, equity satisfaction, disconfirmation satisfaction directly or through an intermediary delivery and professionalism is things that are important in improving the quality of service. Based on the study of literature searches that contained the results of research and the opinion of some experts who say their influence on these variables, including some factors described below.

Employee satisfaction relationship to the service quality

According to [12] employees who feel satisfied with the work performed will tend to provide high value services to customers which in turn will create satisfaction for the customer. Results of research conducted by [13] also supports the idea Kotler and Armstrong that studies proved that job satisfaction has a positive and significant impact on service quality factors. Whereas in 
other studies [14] have shown that job satisfaction has a positive influence on the quality of service.

Relation to quality service delivery

According to [7] that the operating system services are part of the total service system in which inputs will be processed and the elements of the product services have been created. Lovelock's opinion implies that service delivery will affect the quality of service because it is a process from beginning to the end product of the services received.

Professionalism relationship to the service quality

Someone who does not have the ability to actualize himself professionally in the work will affect the quality of the services to be doing so will result in unsatisfactory work, [15] proved that existence of a significant positive effect on the quality of service professionalism of employees. Research on professionalism also been investigated by [16] results of these studies show that employee professionalism variables affect the quality of service at the population and civil registration agency of West Pasaman Regency. This means that the professionalism owned employee was able to improve the quality of public services.

Employee satisfaction relationships, delivery and professionalism of the Service Quality

[17] explains that satisfaction is intrinsically related to a person's needs factor (customer) means that if one's needs are met then that person feels satisfied, and vice versa customers. When the level of employee satisfaction has been achieved it will indirectly affect the quality and service delivery. Thomson and Mori (2004) [15] have found that the research results, professionalism and delivery significantly affects the quality of services and satisfaction of society in the field of public services. From the above description, this research will be presented the conceptual framework of the study as follows.

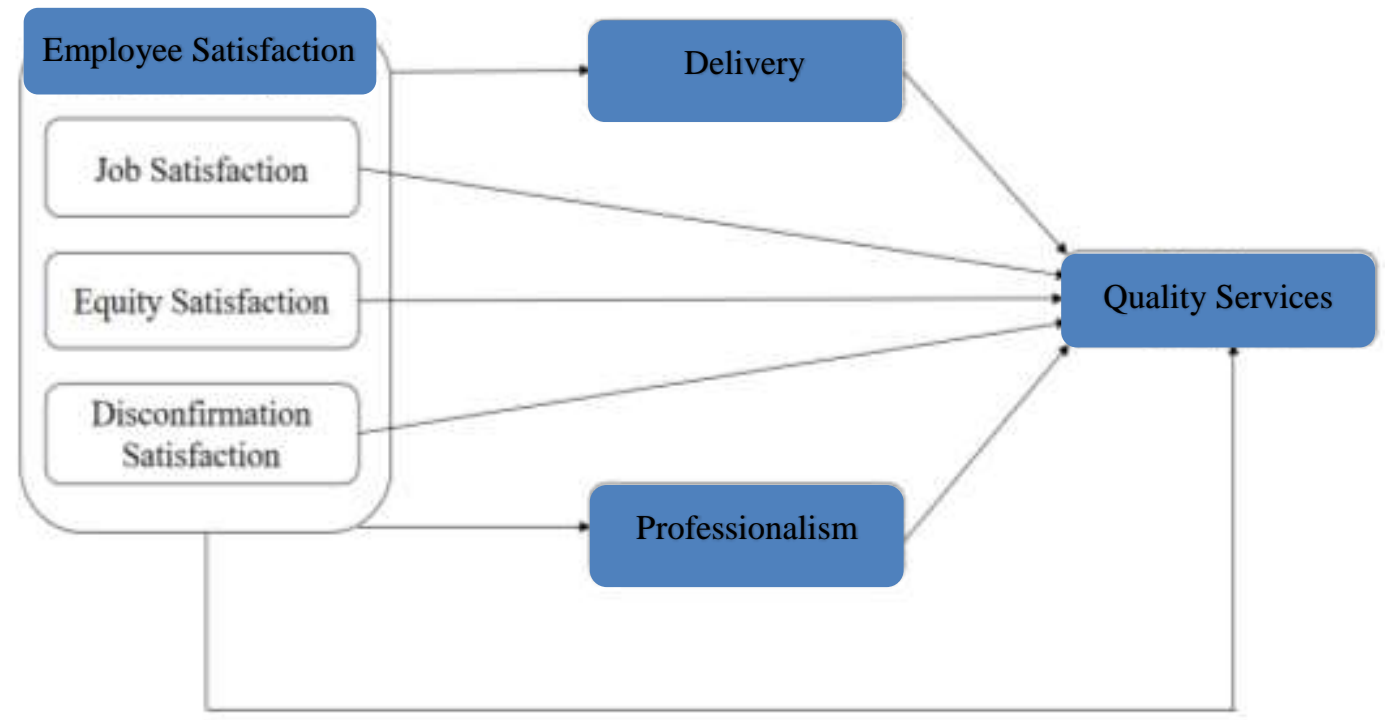

Figure 1. Conceptual Framework of the Research

\section{Hypothesis}

The hypothesis of this study were; 1 ) there is influence employee satisfaction (job satisfaction, equity satisfaction, disconfir mation satisfaction) on the quality of service; 2) satisfaction of employees (job satisfaction, equity satisfaction, disconfirmation satis faction) on delivery and professionalism; 3) there is the influence of delivery and professionalism to quality of service; 4) there is the influence of employee satisfaction (job satisfaction, equity satisfaction, discon firmation satisfaction) on the quality of service through the delivery and professionalism.

\section{METHOD}

The research method used associative quantitative research with the subject employee in the Labor and Industrial Agency of Padang City. Samples were taken by 
proportionate stratified random sampling. Total population is as many as 53 employees. By using samples obtained Slovin formula 47 respondents. Data were collected using a Likert scale questionnaire that had been tested for validity and reliability. In conducting this study two types of data used are primary and secondary data. Before analyzed using path analysis, first done classical assumption test and regression. The purpose of using regression analysis is to make the average estimate and the value of the exogenous variables based on the value of endogenous variable, hypothesis testing characteristics of dependency to predict the average value of exogenous variables on the basis of the value of endogenous variables beyond the range of the sample. In this study the concepts studied variables there are six variables; employee satisfaction differentiated into job satisfaction, equity satisfaction and disconfirmation satisfaction, delivery, the professionalism and quality of service. Where employee satisfaction as exogenous variable, while the professionalism and quality of service designated as an endogenous variable.

\section{RESULTS AND DISCUSSION}

Demographic Research Characteristics

Demographics in question is a descriptive analysis of respondents surveyed. The

Table 2. Results of Regression Testing

\begin{tabular}{|c|c|c|c|c|}
\hline Model & $\mathrm{R}$ & R Square & $\begin{array}{l}\text { Adjusted } \\
\text { Square }\end{array}$ & $\mathrm{R}_{\text {Sig. }}$ \\
\hline $\begin{array}{l}\text { Influence job satisfaction of the quality of service in the } \\
\text { Labor and Industrial Agency of Padang City }\end{array}$ & $.669 a$ & .448 & .436 & .000 \\
\hline $\begin{array}{l}\text { Effect of satisfaction of equities (equity satisfaction) the } \\
\text { quality of service in the Labor and Industrial Agency of } \\
\text { Padang City }\end{array}$ & $.708 a$ & .501 & .490 & .000 \\
\hline $\begin{array}{l}\text { The influence of disconfirmation satisfaction } \\
\text { (disconfirmation satisfaction) on the quality of service in } \\
\text { the Labor and Industrial Agency of Padang City }\end{array}$ & $.513 a$ & .263 & .247 & .000 \\
\hline $\begin{array}{l}\text { Effect of service delivery on the quality of service in the } \\
\text { Labor and Industrial Agency of Padang City }\end{array}$ & $.821 a$ & .673 & .666 & .000 \\
\hline $\begin{array}{l}\text { Influence of professionalism to the quality of service in } \\
\text { the Labor and Industrial Agency of Padang City }\end{array}$ & $.839 a$ & .704 & .698 & .000 \\
\hline
\end{tabular}

information that the demographic characteristics of the study can be grouped four types of groups: gender, age, education level and the average expenditure per month. If the views of gender, respondents in this study is dominated by woman are amounted to $57.7 \%$ of respondents. While for the age group, then that becomes the most respondents are aged between 41-50 years of age range as much as $34 \%$. The third group is from the category of education level, the majority of respondents educated to degree bachelor as much as $51.1 \%$. As for the category of expenses incurred by the respondents on average each month, dominated by respondents expenditure between 25000014000000 as many as 24 people or $51.8 \%$.

Hypothesis Testing

If the statistical data in this research is done by using multiple linear regression analysis and after that were analyzed using path analysis, previous data is first performed classical assumption. Classic assumption test includes: 1) test for normality; 2) test linearity; 3) heteroscedasticity test; and 4) the test multicolinearity. Analysis of classical assumption proved to meet the requirements and have passed the test prerequisites so that the data declared eligible to be analyzed at the next stage of regression. Regression test results can be seen in the table below. 
Effect of employee satisfaction on service delivery at the $\quad .797 a \quad .633$

633

.607

.000

Labor and Industrial Agency of Padang City

Effect of employee satisfaction towards professionalism

$.811 \mathrm{a}$

.657

.633

.000

in the Labor and Industrial Agency of Padang City

Effect of employee satisfaction on the quality of service in .791a

.625

.599

.000

the Labor and Industrial Agency of Padang City

Source: Research 2018 (data processing)

Based on the above table it can be seen the effect and influence of the contribution of each of the exogenous variables to endogenous variables. Statistical data if test results prove that each of the exogenous variables proved significantly affect the quality of service the Labor and Industrial Agency of Padang City. This is evidenced by the acquisition of significant value under $<0: 05$. Significant here also means that the effect caused by each of the exogenous variables on endogenous variables gives a real impact and meaning. Contributions influence given course vary in each variable, but it can be concluded that the biggest contribution occurred in variable professionalism that is contributing influence of $69.8 \%$, while the contribution of the smallest occurred in variable disconfirmation satisfaction with contributions influence of $2: 47 \%$.

Influence of Employee Satisfaction on Service Quality

Statistical tests prove that the hypothesis employee satisfaction variables consisting of job satisfaction, equity satisfaction, and disconfirmation satisfaction are significant effect on the variable quality of service in Labor and Industrial Agency of Padang City. Statistical test results are: influence job satisfaction the quality of services addressing the value of Adjusted R Square of 0436 and the significance value implies that this 0.000 . Number job satisfaction significantly affect the quality of service in Department of Labor and Industry, Padang. The contribution of a given effect is $43.6 \%$. Thus the hypothesis proposed in this study were convicted.

Influence satisfaction of equities (equity satisfaction) the quality of services addressing the value of Adjusted R Square of 0.490 and the significance value implies that this 0.000 .
Number satisfaction of equities (equity satisfaction) significantly affect the quality of service in Labor and Industrial Agency of Padang City. The contribution of a given effect is $49 \%$. Thus the hypothesis proposed in this study was convicted. Influence disconfirmation satisfaction the quality of services addressing the value of Adjusted $R$ Square of 0.247 and the significance value implies that this 0.000 . Number disconfirmation satisfaction (disconfirmation satisfaction) significantly affect the quality of service in Labor and Industrial Agency of Padang City. The contribution of a given effect is $24.7 \%$. Thus the hypothesis proposed in this study was convicted. Influence employee satisfaction Labor and Industrial Agency of Padang City the quality of services addressing the value of Adjusted R Square of 0599 and the significance value implies that this 0.000 . Number employee satisfaction significantly affect the quality of service in Labor and Industrial Agency of Padang City. The contribution of a given effect is $59.9 \%$. Thus the hypothesis proposed in this study was convicted.

Based on the results of the regression test as described above, the researchers obtained a description that influence employee satisfaction variable consisting of job satisfaction, equity satisfaction, and disconfirmation satisfaction has contributed a significant impact on improving the quality of service Labor and Industrial Agency of Padang City in providing services to the public has been proven and tested statistically. Results of research conducted by [18] also supports the idea Kotler and Armstrong that his studies proved and showed results that job satisfaction has a positive and significant impact on service quality factors. In his research, Mela Gusri Rahman in the year 2017 
has also shown that job satisfaction has a positive influence on the quality of service. According to [17] Employees who feel satisfied with the work performed will tend to provide high value services to customers which in turn will create satisfaction for the customer.

Influence of Employee Satisfaction on Service Delivery

The hypothesis proposed here is there is the influence of employee satisfaction to the dimensions of service delivery in Labor and Industrial Agency of Padang City. The test results for the variable employee satisfaction statistic shows the value of Adjusted R Square of 0607 with significant value 0.000 . It can be concluded that there is significant influence amounted to $60.7 \%$ variable employee satisfaction the dimensions of service delivery at the Labor and Industrial Agency of Padang City, so the hypothesis put forward in the study were convicted. Employee satisfaction is a common problem in every unit, whether it is related to motivation, loyalty or quietness working, working and dicipline. Employees who have a high level of satisfaction in the organization tend to be performing well, and in terms of giving to the community waitress prediction also be good, so that it will cause a rise in the level of quality of services provided and to create satisfaction for the people who receive these services.

Influence of Employee Satisfaction on Professionalism

The hypothesis proposed is contained influence employee satisfaction to the dimensions of professionalism in Labor and Industrial Agency of Padang City. The test results for the variable employee satisfaction statistic shows the value of Adjusted R Square of 0.633 with a significance value of 0.000 . It can be concluded that there is significant influence amounted to $633 \%$ variable employee satisfaction the dimensions of professionalism in the Labor and Industrial Agency of Padang City. So the hypothesis put forward in the study were convicted. Employee satisfaction in this study proved to give effect to the professionalism of an employee doing a job. So indirectly it can be concluded that to improve the professionalism of the employees in an institution, a leader must consider the level of job satisfaction of employees. Improve employee satisfaction first then indirectly employees will also work professional. This statement is evident from the results of the data analysis has been done, particularly in the institution Labor and Industrial Agency of Padang City.

Influence Service Delivery on the Quality of Service

The next hypothesis in this study is there are significant dimensions of service delivery to variable quality of service in Labor and Industrial Agency of Padang City. The test results statisic for the dimension service delivery showed the value of Adjusted $R$ Square of 0.666 with significant value 0.000 . It can be concluded that there is significant influence amounted to $66.6 \%$ delivery service on the quality of service in Labor and Industrial Agency of Padang City, So the hypothesis put forward in the study were convicted. According to Lovelock, et. al. (2002: 105) [9] that the operating system services are part of the total service system in which inputs will be processed and the elements of the product services have been created. Services delivery system (service) is part of a total system of service, where final preparation of the elements of the case and the products are delivered to customers including the element of service operations. Opinion Lovelock (2002) [9] implies that service delivery will affect the quality of service because it is a process from beginning to the end product of the services received. Delivery of services is the spearhead of service. The resulting product is not worth the service if it is not accepted by the users of the service. In connection with the arrival of products services to users.

Professionalism Influence on the Quality of Service

The last hypothesis proposed in this research is there are significant dimension of professionalism to the variable quality of service in Labor and Industrial Agency of Padang City. The test results for the dimension 
statistic professionalism showed the value of Adjusted R Square of 0.698 with significant value 0.000 . It can be concluded that there is significant influence amounted to $69.8 \%$ profesionalisme dimensions the quality of service in Labor and Industrial Agency of Padang City. So that the hypothesis proposed in this study expressed proven. This research result supported by research conducted by Andila Mandasari (2014) [16], which prove that the existence of a significant positive effect on the quality of service professionalism of employees. This means that an employeeowned business professionalism was able to improve the quality of public services. Research on professionalism also been investigated by Mahlil Usman in 2017 [17]. The results of these studies show that employee professionalism variables affect the quality of service at the Population and Civil Registration Agency of West Pasaman.

Summary of Analysis and Testing Model

The model is conceived in this study is to describe and determine the effect of employee satisfaction consisting of job satisfaction, equity satisfaction, and disconfirmation satisfaction on the quality of service either directly or indirectly or through an intermediary dimension of service delivery and professionalism. The conception of the study to prove whether or not the variables influence the causes (exogenous) to the result variables (endogenous). Data were analyzed using path analysis previously performed classical assumption test and regression test. Results summary of the model as shown in the drawing and figure below.

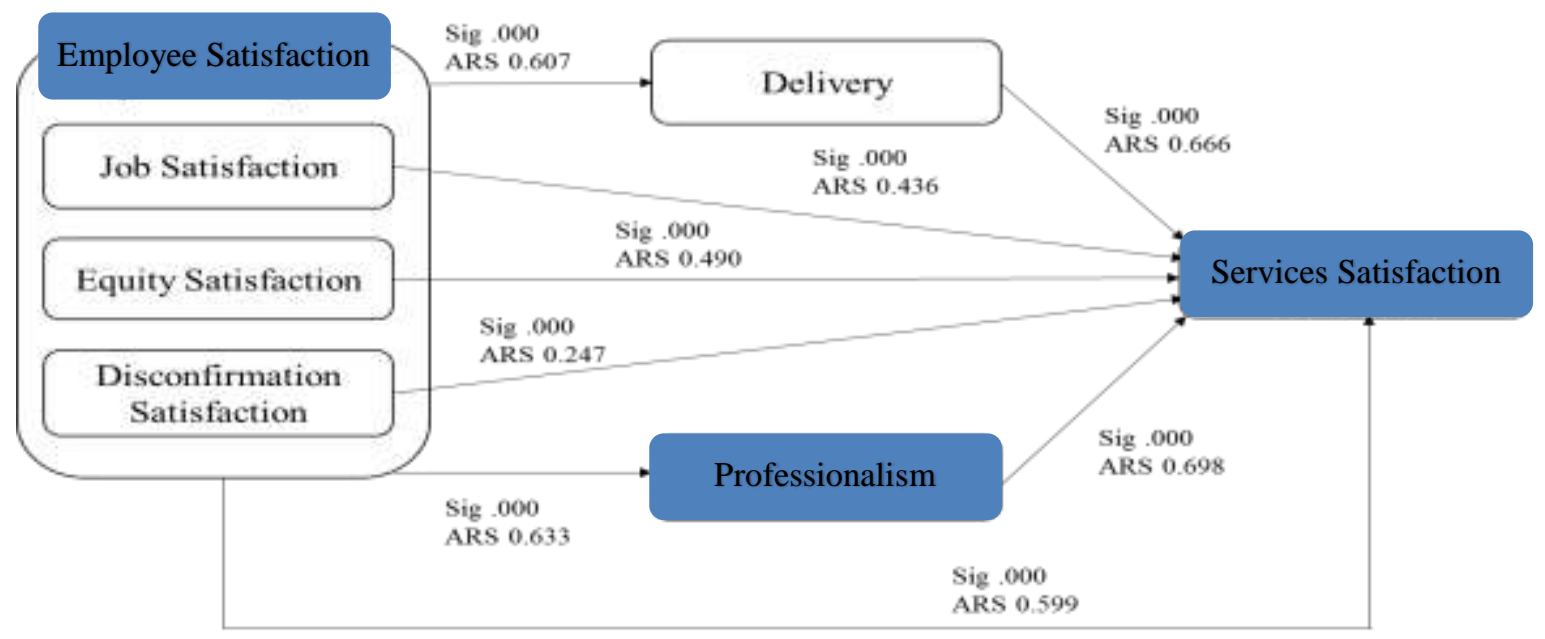

Figure 2.Regression Test Results

Source: Research 2018

In the picture above can be explained that the shape of the relationship and the contribution of each effect of exogenous variables on endogenous variables. In this study it appears that all of the exogenous variables significantly influence endogen variable and the amount of contributions made too varied and different each variable. The picture above also direction of arrows connot effect relationship either directly or indirectly. To see how much contribution the effect of indirectly (through intermediate variables) can be seen in the table below.

Table 3. Summary of Parameter Estimation Model

\begin{tabular}{llll}
\hline Variables & $\begin{array}{l}\text { Direct } \\
\text { Impact }\end{array}$ & $\begin{array}{l}\text { Indirect } \\
\text { Influence }\end{array}$ & $\begin{array}{l}\text { Effect of } \\
\text { Total }\end{array}$ \\
\hline $\begin{array}{l}\text { Effect of employee satisfaction with quality of } \\
\text { services through the dimensions of service } \\
\text { delivery at the Labor and Industrial Agency of }\end{array}$ & $59.9 \%$ & $40.4 \%$ & $100.3 \%$
\end{tabular}


Padang City

Effect of employee satisfaction with quality of services through the dimensions of professionalism in the Labor and Industrial

In the table above describes the results of path analysis of influence direct effect, the indirect effect, and the total effect incurred or caused by each of the exogenous variables on endogenous variables. Contributions effect that occurs vary in value, but it can be concluded that the greatest contribution indirect effect is mediated by the dimensions of professionalism that its contribution of $100.4 \%$.

\section{CONCLUSIONS}

From what has been described previously and the results of the data analysis has been done on employee satisfaction related to quality of service either directly or indirectly on Labor and Industrial Agency of Padang City. Where employee satisfaction here divided into three forms of satisfaction include job satisfaction, equity satisfaction, dan disconfirmation satisfaction and seen also from the two dimensions of service delivery and professionalism, it can be concluded: 1) There is a direct effect of significantly by $43.6 \%$ job satisfaction of the quality of service; 2) There is a direct effect of significantly by $49 \%$ satisfaction of equities (equity satisfaction) to service quality; 3 ) There is a direct effect of significantly by by $24.7 \%$ (disconfirmation satisfaction) to service quality;4) There is a direct effect of significantly by $66.6 \%$ of service delivery on the quality of service; 5 ) There is a direct effect of significantly by $69.8 \%$ of professionalism to the quality of service; 6) There is a direct effect of significantly by $60.7 \%$ employee satisfaction on service delivery; 7) There is a direct effect of significantly by $63.3 \%$ in the professionalism of employee satisfaction; 8) There is a direct effect of significantly by $59.9 \%$ employee satisfaction with quality of services; 9) There is the indirect influence significantly by $40.4 \%$ employee satisfaction with quality of services through service delivery Labor and Industrial Agency of Padang City; and 10) Are the indirect impacts significantly by $44.2 \%$ employee satisfaction with quality of services through profesionalisme at Labor and Industrial Agency of Padang City.

In this study, it appears that the contribution made by each of the exogenous variables, namely job satisfaction, equity satisfaction, and disconfirmation satisfaction has been shown to significantly influence the endogenous variable (delivery, professionalism, and quality of service) in Labor and Industrial Agency of Padang City. So the implications of this research is already time to party Labor and Industrial Agency of Padang City making and seeking to improve employee satisfaction variables through, either job satisfaction, equity satisfaction, disconfirmation satisfaction and make delivery and professionalism dimension as capital and effort to improve the quality of service, because the indirectly quality of service also has a correlation with the external or public satisfaction.

\section{ACKNOWLEDGMENTS}

We want to express special gratitude to all respondents and anyone who has helped during the research.

\section{REFERENCES}

[1] Luthans, Fred. (2006). Perilaku Organisasi, (Alih Bahasa V.A Yuwono, dkk), Edisi Bahasa Indonesia. Yogyakarta: Andi.

[2] Daft, Richard L. (2014). Manajemen. Edisi 1, Alih bahasa oleh Edward Tanujaya dan Shirly Tiolina. Jakarta: Salemba Empat.

[3] Tjiptono, Fandy. (2004). Prinsip-prinsip Total Quality Service. Yogyakarta: Penerbit Andi Offset. 
[4] Tjiptono, Fandy. (2012). Service Management Mewujudkan Layanan Prima.Yogyakarta: CV Andi Offset.

[5] Parasuraman. (1990). Delivery Quality Balancing Customer Perception and Expectation. USA: Free Press Collier Macmillan Publisher.

[6] Lucas, Robert W. (2015). Customer Service: Skills for Success. Fifth Edition. (New York: Mc Graw-Hill Company.

[7] Lovelock and Wright. (2002). Principles of Service Marketing and Management. $2^{\text {nd }}$ edition, Prentice Hall.

[8] Siagian, Sondang P. (2009). Teori Pengembangan Organisasi. Jakarta: Bumi Aksara.

[9] Sedarmayanti. (2004). Restrukturisasi dan Pemberdayaan Organisasi Untuk Menghadapi Dinamika Perubahan Lingkungan. Jakarta: Mandar Maju.

[10] Kurniawan, Agung. (2005). Tranformasi Pelayanan Publik. Yogyakarta: Pembaruan.

[11] Agung S. Tamrin, Patar Rumapea, Rully Mambo. (2017). Pengaruh Profesionalisme Kerja Pegawai Terhadap Kepuasan Pelanggan pada Kantor PT. Taspen Cabang Manado. Jurnal Administrasi Publik FISIP Unsrat, 2(46).

[12] Kotler, P dan Gary Amstrong. (1998). Dasar-dasar Pemasaran, Principles of Marketing 7e, Terjemahan, Alexander Sindoro dan Benyamin Molan. Jakarta: Prenhallindo.

[13] Sukotjo, Hendri. (2011). Pengaruh Kepuasan Kerja terhadap Kualitas Layanan, Kepuasan Pelanggan dan Loyalitas Pelanggan pada Perguruan Tinggi Swasta di Jawa Timur. Jurnal Aplikasi Manajemen, 9(2), pp. 650-658.

[14] Mela Gusri Rahman. (2017). Pengaruh Politik Internal Organisasi dan Kepuasan Kerja terhadap Kualitas Pelayanan di RSUD Kota Padang Panjang. Tesis tidak diterbitkan. Padang: Program Magister Administrasi Publik Fakultas Ilmu Sosial Universitas Negeri Padang.

[15] Thomson, W \& Mori. (2004). Customer Satisfaction with Key Public Services. 